\title{
Relative quantification of TCR Vbeta-chain families by real time PCR for identification of clonal T-cell populations Sebastian Ochsenreither*1, Alberto Fusi ${ }^{1}$, Antonia Busse ${ }^{1}$, Dirk Nagorsen ${ }^{1}$, David Schrama ${ }^{2}$, Jürgen Becker ${ }^{2}$, Eckhard Thiel ${ }^{1}$ and Ulrich Keilholz ${ }^{1}$
}

\author{
Address: ${ }^{1}$ University Hospital Benjamin Franklin, Medizinische Klinik III, Hematology, Oncology, and Transfusion Medicine, Charité \\ Universitätsmedizin Berlin, 12200, Berlin, Germany and 2University of Würzburg, Clinic for Dermatology, Allergology, and Venerology, 97080, \\ Würzburg, Germany \\ Email: Sebastian Ochsenreither* - sebastian.ochsenreither@charite.de; Alberto Fusi - albyjo@yahoo.it; \\ Antonia Busse - antonia.busse@charite.de; Dirk Nagorsen - dirk.nagorsen@charite.de; David Schrama - schrama_d@klinik.uni-wuerzburg.de; \\ Jürgen Becker - becker_jc@klinik.uni-wuerzburg.de; Eckhard Thiel - eckhard.thiel@charite.de; Ulrich Keilholz - ulrich.keilholz@charite.de \\ * Corresponding author
}

Published: I July 2008

Journal of Translational Medicine 2008, 6:34 doi:10.1 186/1479-5876-6-34
Received: 18 February 2008

Accepted: I July 2008

This article is available from: http://www.translational-medicine.com/content/6/1/34

(c) 2008 Ochsenreither et al; licensee BioMed Central Ltd.

This is an Open Access article distributed under the terms of the Creative Commons Attribution License (http://creativecommons.org/licenses/by/2.0), which permits unrestricted use, distribution, and reproduction in any medium, provided the original work is properly cited.

\begin{abstract}
Background: Quantification of T-cell receptor (TCR) chain families can be utilized for detection of clonal T-cell populations. Besides southern blotting and antibody-based approaches, quantitative real time PCR ( $q R T P C R$ ) has been more widely applied in this context during the last years. Here, the heterogeneity of sequences within single families is the most challenging problem for exact quantification.
\end{abstract}

Method: $V \beta$-families were quantified using a universal reverse primer and family-specific forward primers with TaqMan technology on a light cycler instrument. Relative concentrations were calculated considering slopes and crossing points of each PCR reaction. Total expression of $\alpha / \beta$ TCR was assessed by quantification of the constant $\alpha$-chain as a further control.

Results: The method was tested by serial dilutions of clonal T-cells in mononuclear cells from healthy volunteers. Calculated percentages were in good correspondence with qRT PCR results demonstrating high reliability. Duplicates showed excellent technical reproducibility. We analyzed blood samples of 20 healthy volunteers for determination of mean and standard deviation for each family. The method was applied both to tissue and blood samples from patients with carcinomas and hematological disorders.

Conclusion: We introduce a versatile method for the relative quantification of $V \beta$-families by real time PCR. The experimental strategy described allows the identification of alterations in the $V \beta$ family repertoire.

\section{Background}

T-lymphocytes are specialized mediators of the adaptive immune system, selectively destroying cells altered by viral infection or malignant transformation [1,2]. T-cell mediated immune responses are characterized by activation and subsequent clonal expansion of antigen-specific cells. Recognition of Major Histocompatibility Complex class I (MHC-I) bound peptide is mediated by the dimeric 
transmembrane T-cell receptor (TCR) composed of an $\alpha$ and a $\beta$-chain in the majority of cases. The high diversity of these chains is generated by stepwise recombinations of a multitude of variable $(V)$, in case of the $\beta$-chain diversity $(D)$, and joining $(J)$ gene sequences with a corresponding constant $(C)$ chain during thymic T-cell evolution [3]. Vgenes are grouped in families consisting of genes with at least 50\% sequence homology [4].

$\mathrm{T}$ lymphocyte repertoire alterations can be evaluated by TCR-diversity restriction analyses of the sequence or the length of the high variable part of the $\alpha$ - or $\beta$-chains (e. g. spectrotype, SSCP ('single strand conformation polymorphism'), DGGE ('denaturing gradient gel electrophoresis'), heteroduplex analysis [5-11]) or by TCR $V$-family quantification [12-16]. Because of the lower described number of $V \beta$-families compared to $V \alpha$-families, the higher variability of the $\beta$-chain, and the fact that each Tcell clone can express two different $\alpha$-chains but only one $\beta$-chain, the $V \beta$-chain has been largely preferred for this type of analysis $[12,13,17,18]$.

Quantification of $V \beta$-families have been investigated by means of different approaches as southern blotting or, more recently, Fluorescence Activated Cell Sorter (FACS) and quantitative real time reverse transcribed PCR (qRT PCR) [5,12-14]. In contrast to other approaches, PCRbased methods could detect a higher number of different families, had higher selectivity, and were applicable to different specimens. A cumbersome limitation for qRT PCR assessments was the suboptimal establishment of standard dilution curves for exact quantification due to the high heterogeneity of sequences within each family.

Here we introduce a versatile and rapid method for qRT PCR relative quantification of $V \beta$-family expressions based on slope and crossing point of the respective PCR reaction overwhelming therefore the problem of establishing standard dilution curves.

\section{Methods}

\section{Specimen collection}

Peripheral blood samples were drawn form patients and healthy volunteers. Tissue samples were collected from patients with colorectal cancer who underwent therapeutical resection. Both patients and controls had given informed consent for the use of their specimens before sampling. Human T acute lymphoblastic leukemia (ALL) cell lines JURKAT, MOLT-16, and CCRF-CEM were purchased from German Collection of Microorganisms and Cell Cultures (DSMZ) and cultivated under recommended conditions.

\section{RNA extraction and cDNA synthesis}

Total RNA was extracted from peripheral blood mononuclear cells (PBMCs) or fresh tissue using TRIzol ${ }^{\circledR}$ (Invitrogen, Carlsbad, California, USA) or RNeasy ${ }^{\circledR}$ Mini Kit (Qiagen, Hilden, Nordrhein-Westfalen, Germany) according to manufacturers' instructions. RNA was quantified using a NanoDrop ${ }^{\circledR}$ ND-1000 spectrophotometer (Thermo Fisher Scientific, Wilmington, Delaware, USA), and integrity was checked electrophoretically. Reverse transcription was performed with Omniscript Reverse Transcriptase $^{\circledR}$ (Qiagen) as described previously [19]. Samples were stored at $-20^{\circ} \mathrm{C}$.

\section{Relative quantification of $\mathbf{V} \beta$-families}

For estimation of the relative expression of a single TCR $V \beta$-chain, qRT PCRs were performed with a universal reverse primer HBC-rev, a TaqMan probe HBCTP-FAM, both annealing at the constant part of the $\beta$-chain $(C \beta)$, and $V \beta$-family-specific forward primers (modified from [10], Table 1, Figure 1A). Nomenclature of $V \beta$-primers corresponded to the classification of Arden et al [4]. A Mastermix of $19 \mu \mathrm{l}$ for each of the 29 reactions (LightCycler TaqMan Master ${ }^{\circledR}$, Roche, Basel, Switzerland) containing $0.5 \mu \mathrm{M}$ reverse primer HBC-rev, $0.1 \mu \mathrm{M}$ TaqManprobe HBCTP-FAM, and $2 \mu$ template cDNA was prepared. For $V \beta$-family specific amplification, the corresponding forward primer was added to a final concentration of $0.5 \mu \mathrm{M}$. A negative control without forward primer was added. Amplification was performed after an initial denaturation step of $95^{\circ} \mathrm{C}$ for $1 \mathrm{~min}$ in 45 cycles of $95^{\circ} \mathrm{C}$ for $10 \mathrm{sec}, 60^{\circ} \mathrm{C}$ for $30 \mathrm{sec}$, and $72^{\circ} \mathrm{C}$ for 1 sec with data aquisition. The cycling was followed by a terminal elongation step at $72^{\circ} \mathrm{C}$ for $2 \mathrm{~min}$. Crossing points were determined using the Fitpoint algorithm as implemented in LightCycler software 3.0. Slope of each family specific reaction was determined by linear regression analyzing a dilution series $(1,0.1$, and 0.01$)$ of a cDNA mixture of diagnostic samples. The average of these slopes $\bar{s}$ was used for determination of $c^{\prime}$ as described below.

For the calculation of the percentage $P$ of each $V \beta$-family $j$, it was assumed that the effective concentration $c$ of each marker was

$$
\left.c=10^{\left(a+\frac{C_{p}}{\bar{s}}\right.}\right)=10^{a} \cdot 10^{\frac{C_{p}}{\bar{s}}}
$$

where $C_{p}$ was the Crossing point, $\bar{s}\left[\Delta C_{p} / \log (c)\right]$ was the mean slope, and $a$ was considered as an unnown constant for normalization. Defining a linear concentration 
Table I: Primers/probe for quantification of $V \beta$-families (modified from [ 10$]$, TaqMan).

\begin{tabular}{|c|c|}
\hline Primer & Sequence $\left(5^{\prime}-3^{\prime}\right)$ \\
\hline HBVI.I & CAC TCT GAA CTA AAC CTG A \\
\hline HBV2 & TCA ACC ATG CAA GCC TGA CC \\
\hline HBV3 & CGC TTC TCC CTG ATT CTG GAG TCC \\
\hline HBV4 & TTC CCA TCA GCC GCC CAA ACC TA \\
\hline HBV5A & CTG AGA TGA ATG TGA GCA CCT TG \\
\hline HBV5B & CTG AGC TGA ATG TGA ACG CCT TG \\
\hline HBV6A & AGA TCC AGC GCA CAG AGC G \\
\hline HBV6B & AGA TCC AGC GCA CAS AGC A \\
\hline HBV7 & GCC AAG TCG CTT CTC ACC TG \\
\hline HBV8 & TGA AGA TCC AGC CCT CAG AAC CC \\
\hline HBV9 & TCT CAC CTA AAT CTC CAG ACA AAG \\
\hline HBVIO & CCA CGG AGT CAG GGG ACA CA \\
\hline HBVII & TGC CAG GCC CTC ACA TAC CTC TCA \\
\hline HBVI2A & GAG AAT TTC CTC CTC ACT CTG G \\
\hline HBVI2B & GAC CTC CСС СТC ACT CTG G \\
\hline HBVI3A & CTC AGG CTG CTG TCG GCT G \\
\hline HBVI3B & CTC AGG CTG GAG TTG GCT G \\
\hline HBVI4 & AGG GTA CAA AGT CTC TCG AAA AG \\
\hline HBVI5 & CAG GCA CAG GCT AAA TTC TCC \\
\hline HBVI6 & GAA CTG GAG GAT TCT GGA GT \\
\hline HBVI7 & GAA GGG TAC AGC GTC TCT CGG \\
\hline HBVI8 & TTT CTG CTG AAT TTC CCA AAG AGG \\
\hline HBVI9 & TCT CAA TGC CCC AAG AAC GCA C \\
\hline HBV20 & AGG TGC CCC AGA ATC TCT CAG \\
\hline HBV2I & TCA AAG GAG TAG ACT CCA CTC TC \\
\hline HBV22 & AGA TCC GGT CCA CAA AGC TG \\
\hline HBV23 & ATT CTG AAC TGA ACA TGA GCT CCT \\
\hline HBV24 & ATC CAG GAG GCC GAA CAC TTC \\
\hline HBCTP-FAM & FAM-ATG GCT CAA ACA CAG CGA CCT CGG-TAMRA \\
\hline HBC-rev & GGT GTG GGA GAT CTC TGC TTC \\
\hline
\end{tabular}

FAM: 6-carboxyfluorescin; TAMRA: 6-carboxytetramethylrhodamine, S: C or G

A

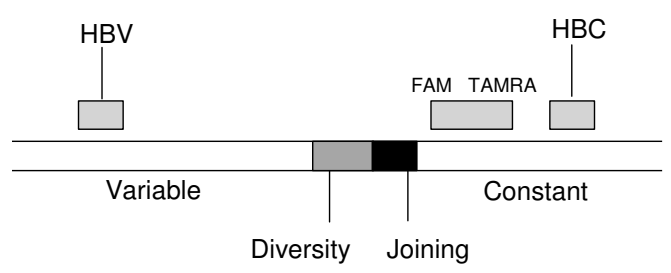

$\mathrm{B}$

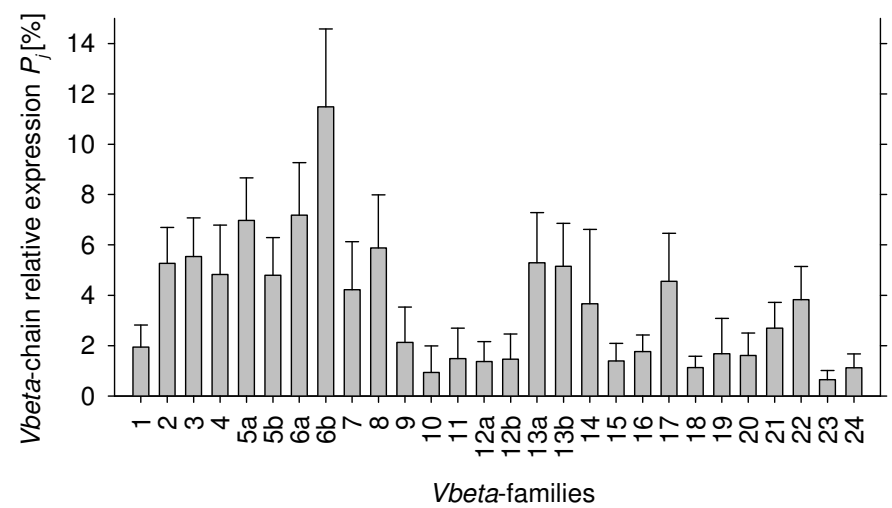

Figure I

Primers and probe annealing sites and $V \beta$-families distribution in peripheral blood of healthy volunteers. (A) Structure of the $\beta$-chain and annealing sites of primers and of the TaqMan probe. Forward primers (HBV) anneal at the variable region, reverse primer $(\mathrm{HBC})$ and TaqMan probe anneal at the constant region (B) Average percentages and standard deviations for $V \beta$-families in PBMCs obtained from 20 healthy controls. Family percentages $P j$ [\%] reflecting single family expression by the sum of all measured $V \beta$-families are shown. 
equivalent $c^{\prime}=10^{\left(\frac{C_{p}}{\bar{s}}\right)}$, the percentage $P[\%]$ of a $V \beta$ family $j$ equaled

$$
P_{j}=\frac{10^{a} \cdot c^{\prime} j^{100}}{\sum_{i=1}^{n}\left(10^{a} \cdot c^{\prime} i\right)}=\frac{c^{\prime} j \cdot 100}{\sum_{i=1}^{n} c^{\prime} i}
$$

assuming a constant $s$ for all families.

\section{Quantification of TCR constant $\alpha$-chain}

For determination of total TCR expression, the TCR constant $\alpha$-chain (HAC) was quantified on a LightCycler $^{\circledast}$ (Roche) as well as the low-abundance housekeeping gene porphobilinogen deaminidase (PBGD) for normalization as described [19]. PCR reactions were optimized using a mixture of cDNA as template. For quantification, LightCycler $^{\circledast}$ FastStart DNA Master HybProbe (Roche) was used. Primer sequences, final $\mathrm{MgCl}_{2}$ concentration, and annealing temperatures $T_{A}$ were listed in Table 2. After optimization of PCR conditions, fragments were amplified conventionally, cloned into a pCR2.1-TOPO vector, and transformed into TOPO10' competent E. coli using TOPO TA Cloning ${ }^{\circledR}$ Kit (Invitrogen). After subcloning in liquid ImMedia $^{\circledR}$ (Invitrogen) and plasmid preparation with QiaMiniprep $^{\circledast}$ Kit (Qiagen), clones were linearized by digesting with EcoR I (Fermentas, St. Leon-Rot, BadenWürttemberg, Germany). Clones were sequenced, quantified spectrophotometrically and serially diluted as concentration standards. Sample concentrations were extrapolated plotting sample-crossing point $C_{p}$ against the regression line through standard- $C_{p}$. RNA quantity was expressed as ratio plasmid equivalent HAC to PBGD.

\section{Results and Discussion}

Slopes of the PCR reactions for all $V \beta$-families were determined by dilution series of a positive control as described (data not shown). The average slope was 3.966 with a standard deviation of 0.61 . This value was used for the cal- culation of family percentages. For assessment of mean value and standard deviation of each family in peripheral blood, PBMCs of 20 healthy volunteers were analyzed (Figure 1B).

For assessment of reliability and reproducibility, samples containing $10^{5}$ PBMCs of three healthy controls were prepared and different amounts of JURKAT-cells were added. JURKAT is a TCR $\alpha / \beta$-expressing T-ALL cell line. Using serial dilution, aliquots of 50, 500, 5000, and 50,000 JURKAT cells were produced and subsequently added to PBMCs. Sample preparation, RNA extraction, cDNA synthesis, and qRT PCR were performed in duplicates for all concentrations for each volunteer. Results were expressed as averages of the calculated percentages of the sample duplicates. The mean difference in the percentage of each $V \beta$-family in all dilution duplicates was $1.01 \%$ indicating excellent technical reproducibility. For all three healthy control PBMCs spiked with JURKAT cells, a clear increase in percentage value of $V \beta$-family 8 was observed comparing 5000 to 500 cells per $10^{5} \mathrm{PBMC}$ (Figure 2A). Assuming $70 \%$ of mononuclear cells in peripheral blood expressing $\beta$-chains and $5.88 \%$ of the tested PBMCs belonging to $V \beta 8$ (average percentage from 20 healthy controls), we calculated the theoretical percentages of family 8 dependent of the amounts of JURKAT cells added, which were in good correspondence with the mean of the measured values from the three healthy controls as shown in Figure 2B. As further validation, cell line MOLT-16 and CCRF-CEM were spiked in PBMCs of volunteer 2 as described above (Figure 3). Percentages of families not expressed by the cell lines relatively decreased at higher amounts of spiked cells. MOLT-16 weakly expressed a second $V \beta$-family, which became apparent at 5000 MOLT-16 cells per $10^{5}$ PBMCs.

Because total amount of TCR $\alpha / \beta$ expression could be different among various types of specimens, we quantified the constant $\alpha$-chain as a control of sample quality. HAC expression was 50-fold higher in PBMCs than in tissue samples (data not shown).

Table 2: Primers/probes sets for quantification of PBGD and C $\alpha$-chain (FRET).

\begin{tabular}{|c|c|c|c|c|}
\hline Primer/probe & Sequence $\left(5^{\prime}-3^{\prime}\right)$ & $\mathrm{T}_{\mathrm{A}}$ & $\begin{array}{l}\mathrm{MgCl} 2 \\
(\mathrm{mM})\end{array}$ & $\begin{array}{l}\text { Standard } \\
\text { dilutions }(\mathrm{pg} / \mu \mathrm{l})\end{array}$ \\
\hline PBGD-fwd & TGC AGG CTA CCA TCC ATG TCC CTG C & $65^{\circ} \mathrm{C}$ & 4 & $1 / 0.1 / 0.001$ \\
\hline PBGD rev & AGC TGC CGT GCA ACA TCC AGG ATG T & & & \\
\hline PBGD-3FI & CGT GGA ATG TTA CGA GCA GCA GTG ATG CCT ACC-FI & & & \\
\hline PBGD-5LC & LC-TGT GGG TCA TCC TCA GGG CCA TCT TC-ph & & & \\
\hline HAC2-fwd & ACA CCT TCT TCC CCA G & $60^{\circ} \mathrm{C}$ & 3 & $10 / 1 / 0.01$ \\
\hline HAC2-rev & TCC AGT TGG TGG CAT T & & & \\
\hline $\mathrm{HAC2}-3 \mathrm{FI}$ & GTG ATT GGG TTC CGA ATC CTC C-FI & & & \\
\hline HAC2-5LC & LC-CTG AAA GTG GCC GGG TTT AAT CT-ph & & & \\
\hline
\end{tabular}

$\mathrm{T}_{\mathrm{A}}$ : Annealing temparature; FI: Fluorescine; LC: LC Red 640; ph: phosphate 
A

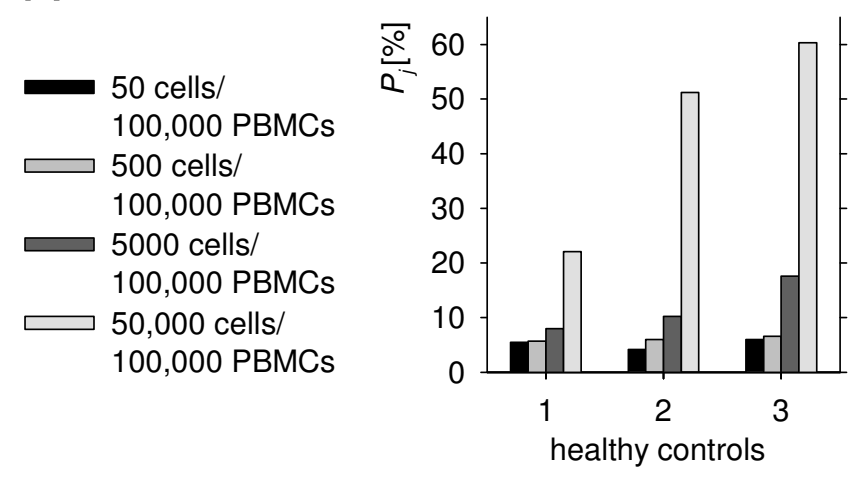

B

calculated measured mean

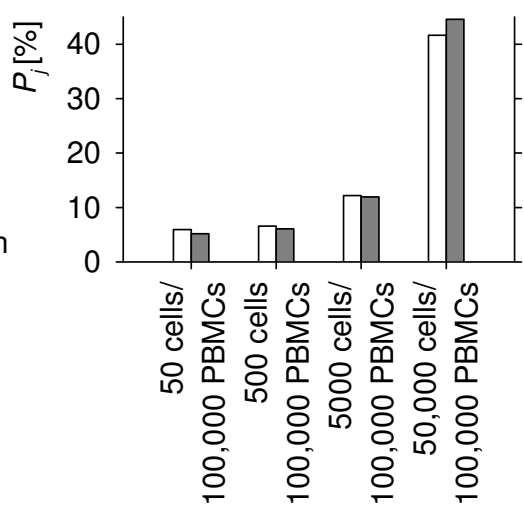

Figure 2

Serial dilutions of JURKAT cells expressing V $\beta$-family 8 spiked in PBMCs of three healthy volunteers. (A) measured percentages of family 8 in case of 50,500, 5000, 50 000 JURKAT cells added to 100000 PBMCs; (B) mean percentages of the three volunteers compared with theoretical values calculated assuming $5.88 \%$ family 8 without JURKAT cells and $70 \%$ TCR $\alpha / \beta$ positive cells in 100000 PBMCs. $P_{j}$ : $\vee \beta$-chain relative expression.

In this study, we introduced a new approach for estimating the distribution of $V \beta$-family expression in a population of T-cells. To determine the effective concentration of a transcript, standard dilutions of the specific fragment are generally utilized. In case of $V \beta$-family analysis, not a single target but a big amount of different close related transcripts has to be quantified because of the high variability of the Complement Determining Region 3 (CDR3) both in length and sequence. Therefore, establishment of a PCR in which a dilution series of a single amplicon (standard curve) is used for normalization, besides increase in costs, can not lead to exact results even using probes annealing to the constant part of the $V \beta$-chain. As PCR reactions lead to an exponential increase of produced fragments, and as a result crossing point values have to be interpreted loga- rithmically concerning the effective concentration of the target, it is possible to calculate percentages without normalization and independently from the sample concentration when crossing points and slope are taken into consideration. For these reasons, in order to by-pass CDR3 diversity, we established a system in which relative quantification is based on the comparison of crossing points, rather than performing a family-by-family quantification using single sequence plasmids for normalization.

There are two drawbacks on the approach: First, because the system is ,normalized' by the sum of its $c^{\prime}$-values, results from runs with more than three lacking crossing points (because of suboptimal sample quality or technical problems) will not be informative. Second, the high standard deviation of the slopes limits the correctness of the mathematical procedure. Exemplary calculations showed that this effect was of no practical relevance as long as the concentration difference between compared samples, reflected by the difference between the sums of all $c^{\prime}\left(c_{\text {total }}^{\prime}\right)$, did not exceed a factor of 100 (data not shown). Nevertheless, this effect may play a role comparing blood with tissue as HAC/PBGD ratio in tissue is lower than in PBMCs. If the difference would be much higher, mathematical corrections of the percentage of a single predominant family should be performed considering $\Delta c_{\text {total }}^{\prime}$ and $s_{j}$.

The method was applied to blood samples of patients with hematological diseases and to colon carcinoma tissues. Three examples with representative $V \beta$ patterns were shown in Figure 4. Pattern $A$ showed the T-cell family repertoire of a patient affected by $\mathrm{T}$ prolymphocytic leukemia with 98.0 leukocytes per $\mathrm{nl}$ and $89 \%$ CD4/CD8 positive cells (FACS analysis, data not shown) in peripheral blood. The pathological clone expressed $V \beta$-family 17 and represented more than $98 \%$ of all TCR $\alpha / \beta$ positive lymphocytes in peripheral blood. Pattern $B$ showed a patient with suspected T-/NK-LGL lymphoproliferation. $V \beta$-families $6 \mathrm{~b}, 22$, and 24 exceeded mean plus two standard deviations as determined in twenty healthy controls. Therefore, a monoclonal TCR $\alpha / \beta$ expressing lymphoproliferation was unlikely and findings had to be interpreted as reactive T cell expansion. Pattern $C$ showed the $V \beta$ family distribution in a representative colon carcinoma tissue sample. A higher percentage of $V \beta$-family 14 compared to other families was observed. If TCR restriction in the tumor compartment reflects a spontaneous expansion of tumor-specific T-cell clones is still matter of debate.

Compared to techniques characterizing the CDR3 region (e.g. spectrotyping, SSCP, DGGE), the method described is less time-consuming and useful for high-throughput screening analyses. As for spectrotyping, conclusive proof 

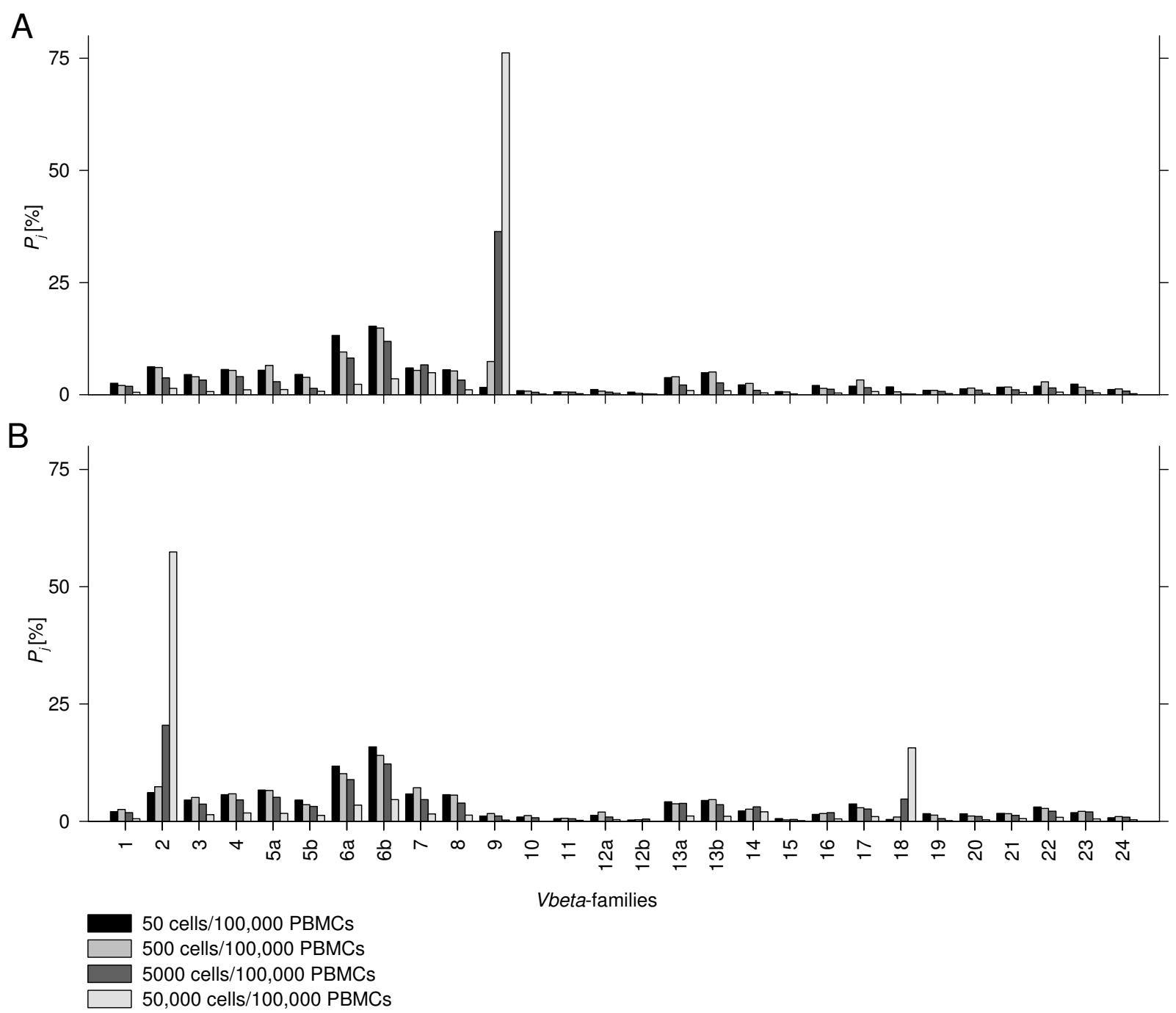

Figure 3

Serial dilutions of CCRF-CEM (V $\beta 9)$ and MOLT-I6 (V $\beta 2, \mathrm{~V} \beta$ I8) cell lines in PBMCs of a healthy volunteer. Measured percentages of all families in case of 50,500, 5000, 50000 CCRF-CEM cells (A) or MOLT-I6 cells (B) added to I00 000 PBMCs of volunteer 2. Dilutions, RNA extraction, cDNA synthesis and qRT PCR are performed in duplicated. Mean percentages of each dilution step were shown. $P_{j}: V \beta$-chain relative expression.

of clonality can only be achieved by sequencing. Approaches like TC landscape combine CDR3 length analysis with $V \beta$-family quantification by FACS quantification in order to improve sensitivity [5]. Due to higher number of detectable families and higher sensitivity, the use of a high-throughput PCR-based quantification algorithm could make a combined approach even more effective [16].

\section{Conclusion}

We present a novel and versatile approach for highthroughput $V \beta$ family quantification. Our approach is suitable for samples from blood or bone marrow as well as from tissue. Because of high reproducibility, compara- tive analyses of samples in different time points or from different compartments are possible.

\section{Competing interests}

The authors declare that they have no competing interests.

\section{Authors' contributions}

SO and AF carried out most of the molecular applications. SO developed the mathematical algorithm and did the calculations and the data analysis. AB did the qRT PCR quantification of HAC and PBGD. DN was responsible for collection and storage of blood and tissue samples. DS and JB built up qRT PCRs for family quantification which were used as basis for the LightCycler approach. ET and 


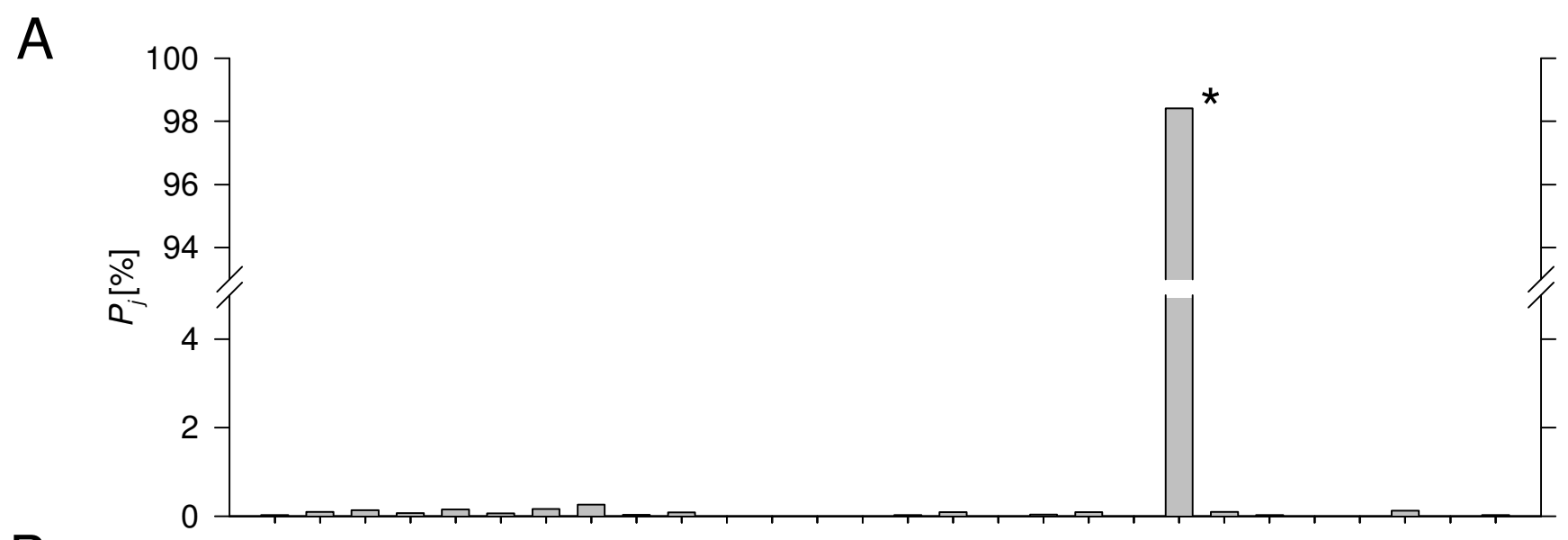

B

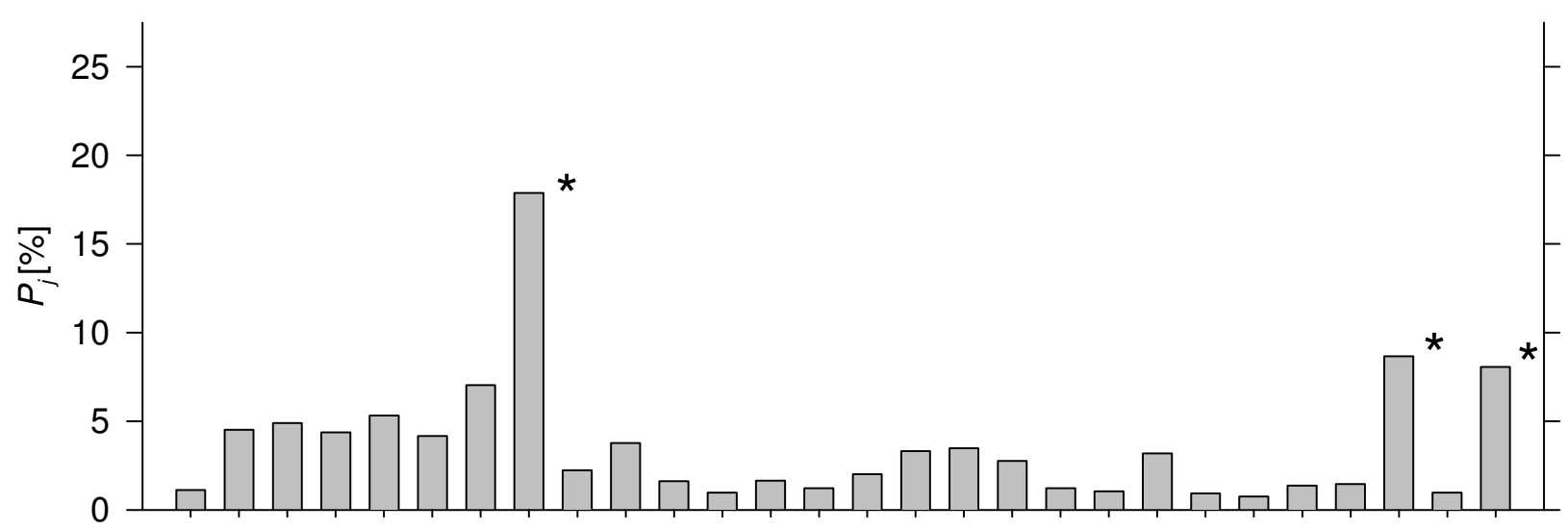

C

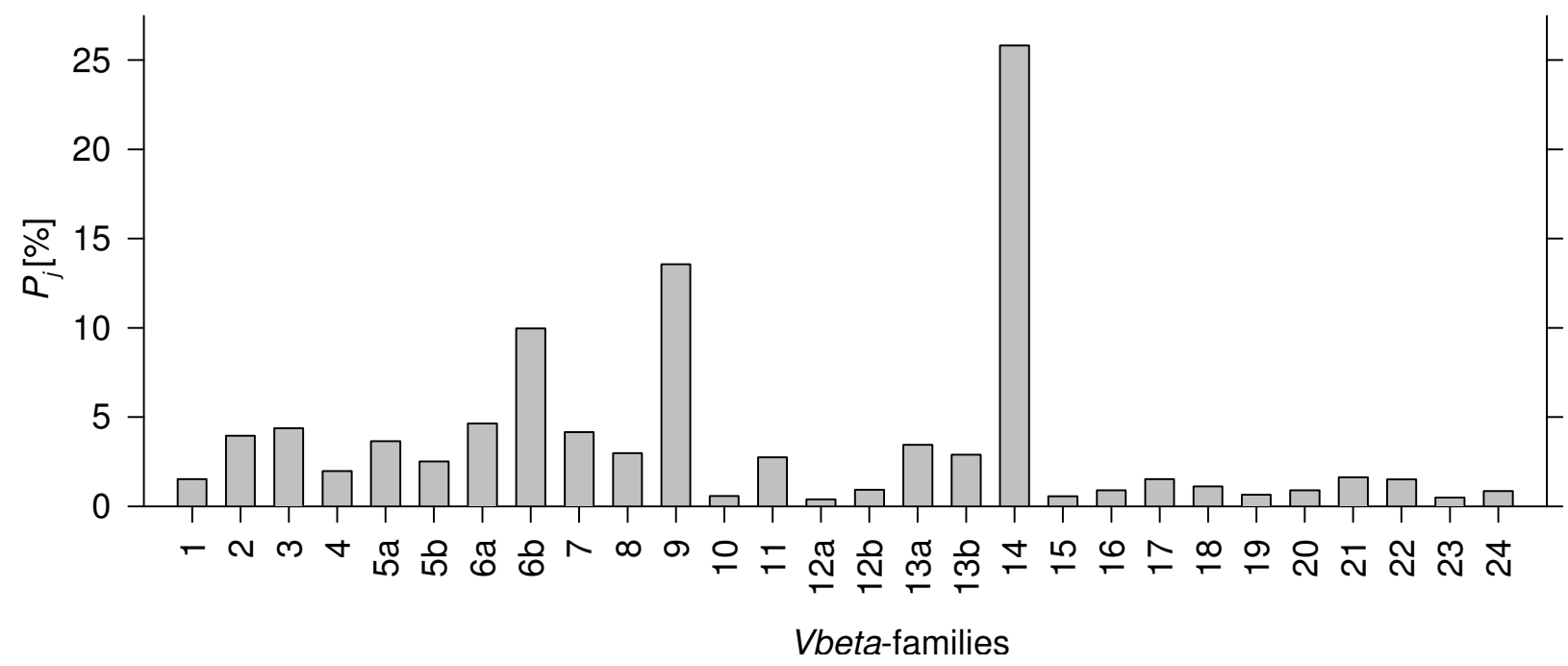

Figure 4

Relative quantification of TCR-V $\beta$-families: Examples of clinical samples. (A) T prolymphocytic leukemia, (B) suspected T/NK-LGL lymphoproliferation, (C) Colon carcinoma tissue. Peripheral blood $V \beta$-chain values (A, B) exceeding mean plus two standard deviations in healthy controls are marked with asterisk. $P_{j}: V \beta$-chain relative expression. 
UK coordinated the laboratory work and helped to draft the manuscript. All authors read and approved the final manuscript.

\section{Acknowledgements}

We thank Susanne Wojtke for excellent technical assistance.

\section{References}

I. Andersen MH, Schrama D, Thor Straten P, Becker JC: Cytotoxic T Cells. J Invest Dermatol 2006, I 26(I):32-4I.

2. Boon T, Coulie PG, Van den Eynde BJ, van der Bruggen P: Human T Cell Response Against Melanoma. Annu Rev Immunol 2006, 24: $175-208$.

3. Davis MM, Bjorkman PJ: T cell antigen receptor genes and $\mathbf{T}$-cell recognition. Nature 1988, 334(6 I8I):395-402.

4. Arden B, Clark SP, Kabelitz D, Mak TW: Human T-cell receptor variable gene segment families. Immunogenetics 1995, 42(6):455-500.

5. Pilch H, Höhn H, Freitag K, Neukirch C, Necker A, Haddad P, Tanner $B$, Knapstein PG, Maeurer MJ: Improved assessment of T-cell receptor (TCR) VB repertoire in clinical specimens: combination of TCR-CDR3 spectratyping with flow cytometrybased TCR VB frequency analysis. Clin Diagn Lab Immunol 2002, 9(2):257-266.

6. Yao XS, Diao Y, Sun WB, Luo JM, Qin M, Tang XY: Analysis of the CDR3 length repertoire and the diversity of TCR alpha chain in human peripheral blood T lymphocytes. Cell Mol Immunol 2007, 4(3):215-220.

7. Long SA, Khalili J, Ashe J, Berenson R, Ferrand C, Bonyhadi M: Standardized analysis for the quantification of Vbeta CDR3 T-cell receptor diversity. J Immunol Methods 2006, 3 I 7( I-2): I00-I I3.

8. Collette A, Cazenave PA, Pied S, Six A: New methods and software tools for high throughput CDR3 spectratyping. Application to $\mathbf{T}$ lymphocyte repertoire modifications during experimental malaria. J Immunol Methods 2003, 278(I2): $105-116$.

9. Chino $Y$, Murata H, Goto D, Matsumoto I, Tsutsumi A, Sakamoto T, Ohtsuka M, Sekisawa K, Ito S, Sumida T: T cell receptor BV gene repertoire of lymphocytes in bronchoalveolar lavage fluid of polymyositis/dermatomyositis patients with interstitial pneumonitis. Int J Mol Med 2006, I 7:101-109.

10. thor Straten P, Barfoed A, Seremet T, Saeterdal I, Zeuthen J, Guldberg P: Detection and characterization of alpha-beta-T-cell clonality by denaturing gradient gel electrophoresis (DGGE). Biotechniques 1998, 25(2):244-250.

II. van Dongen J, Langerak AW, Brüggemann M, Evans PA, Hummel M, Lavender FL, Delabesse E, Davi F, Schuuring E, García-Sanz R, van Krieken JH, Droese J, González D, Bastard C, White HE, Spaargaren M, González M, Parreira A, Smith JL, Morgan GJ, Kneba M, Macintyre EA: Design and standardization of PCR primers and protocols for detection of clonal immunoglobulin and $\mathrm{T}$-cell receptor gene recombinations in suspect lymphoproliferations: report of the BIOMED-2 Concerted Action BMH4-CT983936. Leukemia 2003, I 7(I 2):2257-23I7.

12. Willhauk M, Möhler T, Scheibenbogen C, Pawlita M, Brossart P, Schmier JW, Keilholz U: T-cell receptor beta variable region diversity in melanoma metastases after interleukin 2-based immunotherapy. Clin Cancer Res 1996, 2(4):767-772.

13. Brewer JL, Ericson SG: An improved methodology to detect human $T$ cell receptor beta variable family gene expression patterns. J Immunol Methods 2005, 302( I-2):54-67.

14. Lim A, Baron V, Ferradini L, Bonneville M, Kourilsky P, Pannetier C: Combination of MHC-peptide multimer-based $\mathrm{T}$ cell sorting with the Immunoscope permits sensitive ex vivo quantitation and follow-up of human CD8+ $\mathrm{T}$ cell immune responses. J Immunol Methods 2002, 26 I ( I-2): I77-I 94.

15. Sun W, Popat U, Hutton G, Zang YC, Krance R, Carrum G, Land GA, Heslop H, Brenner M, Zhang JZ: Characteristics of T-cell receptor repertoire and myelin-reactive $T$ cells reconstituted from autologous haematopoietic stemm-cell grafts in multiple sclerosis. Brain 2004, I 27(Pt 5):996-1000.

16. Degauque N, Schadendorf D, Brouard S, Guillet M, Sébille F, Höhn H, Pallier A, Ruiz C, Dupont A, Chapin S, Hofmann U, Maeurer M, Soulil- lou JP: Blood T-cell Vbeta transcriptome in melanoma patients. Int J Cancer 2004, I I 0(5):72I-729.

17. Gagne K, Brouard S, Giral M, Sebille F, Moreau A, Guillet M, Bignon JD, Imbert BM, Cuturi MC, Soulillou JP: Highly altered V beta repertoire of $T$ cells Infiltrating long-term rejected kidney allografts. J Immunol 2000, I64(3): I553-I563.

18. Thor Straten P, Schrama D, Andersen MH, Becker JC: T-cell clonotypes in cancer. J Transl Med 2004, 2(I): II.

19. Keilholz U, Goldin-Lang P, Bechrakis NE, Max N, Letsch A, Schmitte A, Scheibenbogen C, Heufelder K, Eggermont A, Thiel E: Quantitative detection of circulating tumor cells in cutaneous and ocular melanoma and quality assessment by real-time reverse transcriptase-polymerase chain reaction. Clin Cancer Res 2004, I 0(5): 1605-1612.
Publish with Bio Med Central and every scientist can read your work free of charge

"BioMed Central will be the most significant development for disseminating the results of biomedical research in our lifetime. "

Sir Paul Nurse, Cancer Research UK

Your research papers will be:

- available free of charge to the entire biomedical community

- peer reviewed and published immediately upon acceptance

- cited in PubMed and archived on PubMed Central

- yours - you keep the copyright 